\title{
KOMPARASI KEPADATAN DAN PERTUMBUHAN PENDUDUK ANTARA URBAN (PERKOTAAN) DAN RURAL (PERDESAAN) DI KOTA PAYAKUMBUH
}

\author{
Dwi Arianda Rahman \\ Program Studi Geografi \\ Fakultas Ilmu Sosial, Universitas Negeri Padang \\ Email : wandadwi230696@gmail.com
}

\begin{abstract}
ABSTRAK
Penelitian ini bertujuan untuk mengetahui (1) Perbandingan kepadatan penduduk antara perkotaan dan perdesaan di Kota Payakumbuh,(2) Perbandingan pertumbuhan penduduk antara perkotaan dan perdesaan di Kota Payakumbuh, (3) Perubahan penggunaan lahan untuk kawasan permukiman antara perkotaan dan perdesaan di Kota Payakumbuh. Jenis Penelitian ini adalah kuantitatif dengan menggunakan metode deskriptif. Jenis data yaitu data sekunder.Teknik pengumpulan data dengan melakukan survey data dan analisis citra quickbird. Hasil penelitian memperlihatkan bahwa (1) Kepadatan penduduk tahun 2007-2016 di perkotaan kepadatan penduduknya 19,11-23,82 jiwa/ha tergolong sedang, di perdesaan 7,03-8,44 jiwa/ha tergolong jarang. (2)Pertumbuhan penduduk antara perkotaan dan perdesaan tahun 2007-2016, pertumbuhan penduduk di perkotaan 2,22\% pertahun tergolong cepat, pertumbuhan penduduk di perdesaan $1,84 \%$ pertahun tergolong lambat. (3) Perubahan penggunaan lahan untuk kawasan permukiman dari tahun 2007-2016 di perkotaan bertambah 449 ha, perubahan kawasan permukiman di perdesaan bertambah 225 ha.
\end{abstract}

Kata Kunci: Kepadatan, Pertumbuhan, Penduduk, Penggunaan Lahan, Kawasan Permukiman, Urban (Perkotaan) dan Rural (Pedesaan).

\begin{abstract}
This research aims to find out (1) comparison of population density between urban and rural in Payakumbuh, (2) a comparison of population growth between urban and rural in Payakumbuh, (3) land use change to the area of settlement between the urban and the rural in Payakumbuh. This Research type is quantitative descriptive methods. Types of data i.e. secondary data. Data collection techniques by conducting surveys of the quickbird image data and analysis. The research results showed that (1) the population density of the year 2007-2016 in urban population density 19,11-23,82 inhabitants/ha belongs to the medium, in rural 7.03-8.44 inhabitants/ha classified as rare. (2) Population growth between urban and rural population growth 2007-2016 year, 2.22\% per year in urban areas belong to fast, population growth in rural $1.84 \%$ per year belongs to slow. (3) change the use of land for settlement in the area from the years 2007-2016 in urban areas increased by 449 ha, rural settlements in areas of change increased 225 ha.
\end{abstract}

Key words: Density, Growth, Population, Land use, Settlement Areas, Urban (urban areas) and Rural (Rural).

${ }^{1}$ Mahasiswa Program Studi Geografi untuk Wisuda Maret 2018 


\section{PENDAHULUAN}

Penduduk merupakan kelompok manusia yang menempati suatu wilayah tertentu. Daerah atau wilayah tempat hidup penduduk itu tetap, tidak bertambah luas sedangkan penduduk terus bertambah banyak setiap tahunnya karena adanya yang lahir dan meninggal. Bidang kependudukan khususnya menghadapi masalah yang sangat penting yaitu jumlah penduduk yang semakin lama semakin bertambah banyak, pertumbuhan penduduk yang semakin cepat dan kepadatan penduduk yang tidak merata.

Menurut Munir dan Budiharto (1990) penduduk merupakan sejumlah orang yang menempati suatu habitat geografis, memperoleh kehidupan dari habitatnya dan berinteraksi antara yang satu dengan yang lainnya. Keadaan penduduk di suatu daerah atau wilayah selalu mengalami perubahan dari waktu ke waktu. Perubahan ini sangat jelas terlihat pada suatu kota, Pertambahan penduduk di wilayah kota selalu diikuti oleh peningkatan kebutuhan akan ruang untuk tempat tinggal. Wilayah kota merupakan suatu daerah yang memiliki tingkat kepadatan dan pertumbuhan penduduk yang sangat cepat dan padat. Kepadatan dan pertumbuhan penduduk di kota akan mengalami perubahan dan perkembangan dalam tiap tahun. Pertumbuhan dan Kepadatan suatu kota didominasi oleh konsentrasi kegiatankegiatan utama di bagian pusat kota dan dikelilingi oleh daerah permukiman.

Permukiman merupakan salah satu kebutuhan pokok manusia (kebutuhan primer) yang harus terpenuhi agar manusia dapat sejahtera dan hidup layak sesuai dengan derajat kemanusiannya. Perkembangan permukiman sangat dipengaruhi oleh penghuni permukiman itu sendiri. Dengan adanya kepadatan dan pertumbuhan penduduk yang semakin pesat akan mengakibatkan kebutuhan permukiman semakin besar. Masalah ini hampir terjadi di setiap daerah perkotaan, karena kota merupakan daerah yang sangat dinamis yaitu pertumbuhan penduduknya setiap hari semakin bertambah banyak, sehingga daerah perkotaan menghadapi ancaman semakin tingginya kepadatan penduduk dan kepadatan tempat tinggal yang merupakan indikator penurunan kualitas lingkungan permukiman.

Kota merupakan kawasan permukiman dengan jumlah dan kepadatan penduduk yang relatif tinggi, memiliki luas areal terbatas, pada umumnya bersifat non agraris, tempat sekelompok orang-orang dalam jumlah tertentu dan bertempat tinggal bersama dalam suatu wilayah geografis tertentu, cenderung berpola hubungan rasional, ekonomis dan individualis. Perkembangan suatu perkotaan biasanya diawali dari pertumbuhan pusat kota. Pusat kota merupakan pusat aktitivitas yang terjadi pada kota tersebut. Pusat kota ini ditandai dengan adanya pusat perekonomian, pusat pemerintahan, maupun pusat aktivitas campuran yang membentuk CBD (central bussins district).

Keterpusatan perkotaan menyebabkan perubahan fungsi dari yang semula merupakan pusat kegiatan pemerintahan atau jasa dan pelayanan umum lainnya menjadi kegiatan lain, misalnya perdagangan. Adanya 
kemungkinan perkembangan yang cukup besar dari masing-masing kegiatan tanpa diikuti oleh kesempatan perkembangan yang cukup karena ruang atau wilayah yang terbatas, hal ini dapat menyebabkan terjadinya penyebaran kegiatan tersebut ke wilayah luar atau perdesaan. Perdesaan merupakan daerah yang letakya berbatasan dengan daerah lain, baik itu daerah perkotaan maupun daerah lainnya.

Kepadatan dan pertumbuhan kota pada hakekatnya disebabkan oleh jumlah kepadatan dan pertumbuhan penduduk. Sejalan dengan selalu meningkatnya kepadatan dan pertumbuhan penduduk perkotaan serta meningkatnya kebutuhan dalam berbagai aspek telah mengakibatkan meningkatnya kegiatan penduduk perkotaan. Baik meningkatnya kepadatan dan pertumbuhan penduduk perkotaan maupun kegiatan penduduk perkotaan yang telah mengakibatkan kebutuhan ruang yang besar. Karena ketersediaan ruang di perkotaan tetap dan terbatas, maka meningkatnya ruang untuk tempat tinggal akan selalu mengambil ruang di daerah perdesaan. Hal tersebut mengakibatkan semakin tersebarnya penduduk kearah perdesaan sehingga juga mengakibatkan pertumbuhan dan kepadatan penduduk di perdesaan semakin bertambah.

Menurut Undang-Undang

Penataan Ruang No. 26 Tahun 2007 tentang klasifikasi kota, Kota Payakumbuh tergolong kota sedang, yang jumlah penduduk berkisar pada 100.000 hingga 500.000 jiwa. Ciri-ciri dari perkotaan dan perdesaan dilihat dari kepadatan penduduk, pekerjaan, pusat perdagangan, pusat perkantoran, aksesibilitas, penggunaan lahan dan lain-lain. Dalam penelitian ini penulis akan membandingkan kepadatan dan pertumbuhan penduduk serta perubahan lahan untuk kawasan permukiman antara perkotaan dan perdesaan di Kota Payakumbuh.

Bedasarkan data BPS tahun 2010, laju pertumbuhan penduduk Kota Payakumbuh pada tahun 2000-2010 tercatat 1,79. Angka tersebut lebih tinggi dari pertumbuhan penduduk Sumatera Barat pada periode yang sama pada kisaran 1,14. Bedasarkan hasil sensus penduduk yang dilakukan oleh Badan Pusat Statistik jumlah penduduk Kota Payakumbuh tahun 2015 berjumlah 127.826 jiwa. Dilihat dari penggunaan lahan Kota Payakumbuh tidak semua kawasan permukiman, hanya pada kawasan-kawasan tertentu.

Kota Payakumbuh merupakan kota terluas ketiga di Sumatera Barat. Bedasarkan Peraturan Daerah Kota Payakumbuh Nomor 12 dan 13 tahun 2008, Kota Payakumbuh memiliki lima kecamatan, yaitu Kecamatan Payakumbuh Barat, Kecamatan Payakumbuh Utara, Kecamatan Payakumbuh Timur, Kecamatan Payakumbuh Selatan, dan Kecamatan Lamposi Tigo Nagari.

Bedasarkan uraian diatas, penulis merasa perlu untuk mengetahui tentang perbandingan kepadatan dan pertumbuhan penduduk antara perkotaan dan perdesaan di Kota Payakumbuh. Karena jumlah penduduk di kota yang selalu bertambah dari tahun ke tahun hal ini akan mengakibatkan kebutuhan lahan 
permukiman akan semakin besar, sehingga perkembangan dan pertumbuhan penduduk selalu mengalami perubahan dalam tiap tahunnya. Hal ini juga mengakibatkan penggunaan lahan untuk kawasan permukiman akan mengalami perubahan seiring dengan bertambahnya jumlah penduduk yang mengakibatkan permukiman juga bertambah. Oleh sebab itu perlu diungkapkan dalam suatu penelitian yang berjudul "Komparasi Kepadatan dan Pertumbuhan Penduduk Antara Urban (Perkotaan) dan Rural (Pedesaan) di Kota Payakumbuh"

\section{METODE PENELITIAN}

Bedasarkan rumusan dan tujuan penelitian, maka jenis penelitian yang digunakan adalah penelitian deskriptif kuantitatif. Menurut Arikunto (2010) metode ini yaitu penelitian yang dituntut menggunakan angka, mulai dari pengumpulan data, penafsiran terhadap data, serta penampilan dari hasilnya. Penelitian ini bermaksud untuk mengetahui perbandingan kepadatan dan pertumbuhan penduduk antara perkotaan dan perdesaan serta perubahan penggunaan lahan untuk kawasan permukiman antara perkotaan dan perdesaan di Kota Payakumbuh. Lokasi penelitian dilakukan di Kota Payakumbuh. Untuk lebih jelasnya, berikut peta administrasi Kota Payakumbuh :

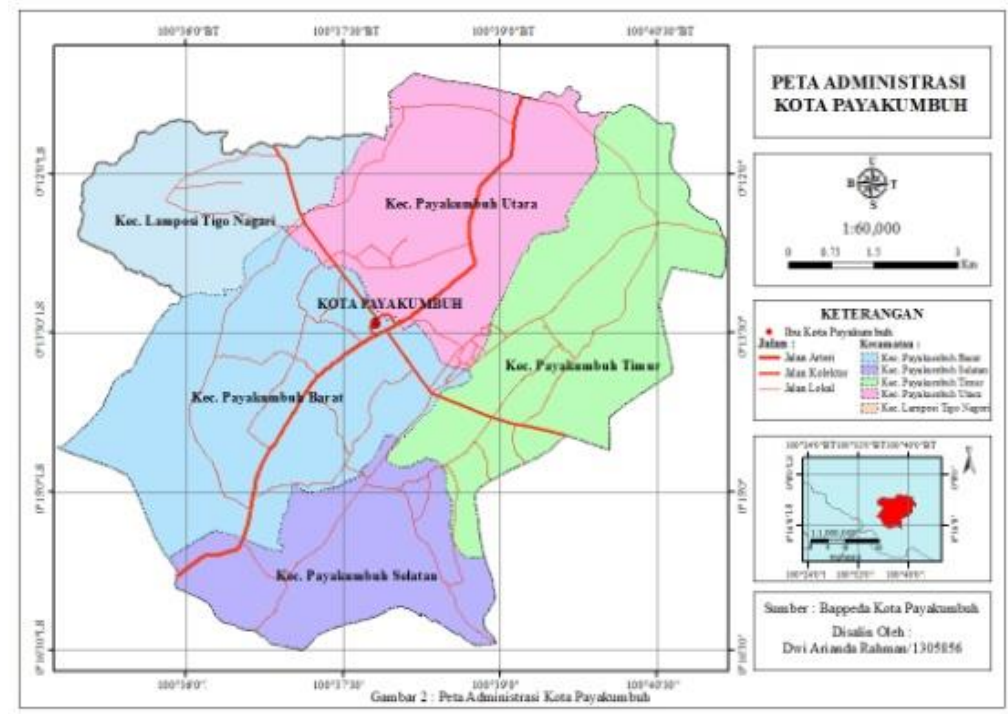

Gambar 1 : Peta Administrasi Kota Payakumbuh

\section{HASIL DAN PEMBAHASAN}

Kota Payakumbuh terletak di Propinsi Sumatera Barat. Secara geografis Kota Payakumbuh terletak pada posisi $00^{\circ}-10^{0}$ sampai dengan $0^{\circ}$ $17^{\prime}$ LS dan $100^{\circ}-35^{\prime}$ sampai dengan $100^{\circ}-48^{\prime}$ BT dengan luas wilayah \pm
$80,43 \mathrm{Km}^{2}$ atau setara dengan 0,19\% dari luas Propinsi Sumatera Barat.

Menurut Peraturan Badan Pusat Statistik Nomor 37 Tahun 2010 Tentang Klasifikasi Perkotaan dan Perdesaan di Kota Payakumbuh. Kelurahan yang berklasifikasi perkotaan berjumlah 53 kelurahan sedangkan kelurahan yang 
berklasifikasi perdesaan berjumlah 23 kelurahan.

1. Kepadatan penduduk antara perkotaan dan perdesaan di Kota Payakumbuh

a. Kepadatan penduduk antara perkotaan dan perdesaan 2007

Untuk mengetahui kepadatan penduduk antara perkotaan dan

Tabel 1: Hasil Analisis Kepadatan Penduduk Antara Urban (Perkotaan) dan Rural (Perdesaan) di Kota Payakumbuh Tahun 2007

\begin{tabular}{|c|c|c|c|r|r|}
\hline No & Klasifikasi & $\begin{array}{c}\text { Luas } \\
\text { Wilayah } \\
\text { (Ha) }\end{array}$ & $\begin{array}{c}\text { Jumlah } \\
\text { Penduduk } \\
\mathbf{2 0 0 7}\end{array}$ & $\begin{array}{c}\text { Kepadatan } \\
\text { Penduduk } \\
\text { (Jiwa/Ha) }\end{array}$ & Kategori \\
\hline 1 & Perkotaan & 4.308 & 82.343 & 19,11 & Sedang \\
\hline 2 & Perdesaan & 3.218 & 22.630 & 7,03 & Jarang \\
\hline \multicolumn{2}{|c|}{ Jumlah } & 7.526 & 104.973 & 13,94 & Sedang \\
\hline
\end{tabular}

Sumber :Pengelolaan Data Sekunder 2017

Bedasarkan tabel 1, kepadatan penduduk tahun 2007 di perkotaan jauh lebih tinggi dibandingkan dengan kepadatan penduduk di perdesaan. Kepadatan penduduk di perkotaan 19,11jiwa/ha, yang artinya dalam 1 ha terdapat 19 jiwa. Sedangkan di perdesaan yaitu dengan menjumlahkan seluruh jumlah penduduk dan luas wilayah kelurahan yang berklasifikasi perkotaan dan perdesaan. Berikut hasil kepadatan penduduk antara perkotaan dan perdesaan di Kota Payakumbuh dapat dilihat pada tabel berikut :

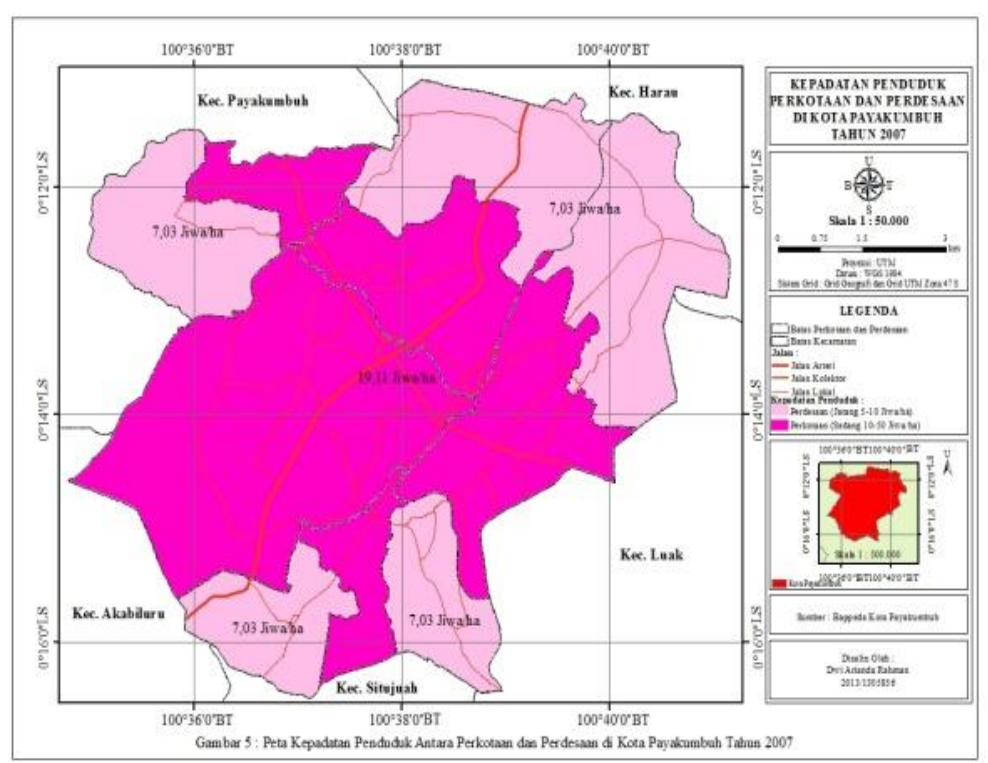

Gambar 2 : Peta Kepadatan Penduduk Perkotaan dan Perdesaan Tahun 2007

b. Kepadatan penduduk antara perkotaan dan perdesaan 2011 
Tabel 2: Hasil Analisis Kepadatan Penduduk Antara Urban (Perkotaan) dan Rural (Perdesaan) di Kota PayakumbuhTahun 2011

\begin{tabular}{|c|c|r|r|r|r|}
\hline No & Klasifikasi & $\begin{array}{c}\text { Luas } \\
\text { Wilayah } \\
\text { (Ha) }\end{array}$ & $\begin{array}{c}\text { Jumlah } \\
\text { Penduduk } \\
\mathbf{2 0 1 1}\end{array}$ & $\begin{array}{c}\text { Kepadatan } \\
\text { Penduduk } \\
\text { (Jiwa/Ha) }\end{array}$ & Kategori \\
\hline 1 & Perkotaan & 4.308 & 95.617 & 22,19 & Sedang \\
\hline 2 & Perdesaan & 3.218 & 26.975 & 8,38 & Jarang \\
\hline \multicolumn{2}{|c|}{ Jumlah } & 7.526 & 122.592 & 16,28 & Sedang \\
\hline
\end{tabular}

Sumber: Pengolahan Data Sekunder 2017

Bedasarkan tabel 2, kepadatan penduduk tahun 2011 di perkotaan jauh lebih tinggi dibandingkan dengan kepadatan penduduk di perdesaan. Kepadatan penduduk di perkotaan 22,19jiwa/ha bertambah 3,08 jiwa/ha dari tahun 2007, sedangkan di perdesaan kepadatan penduduk yaitu $8,38 \mathrm{jiwa/ha}$ bertambah $1,35 \mathrm{jiwa} / \mathrm{ha}$ daritahun 2007. Hal ini menunjukkan Kota Payakumbuh masih berstatus kota sedang, yang mana kepadatan penduduknya masih berkembang di wilayah perkotaan.

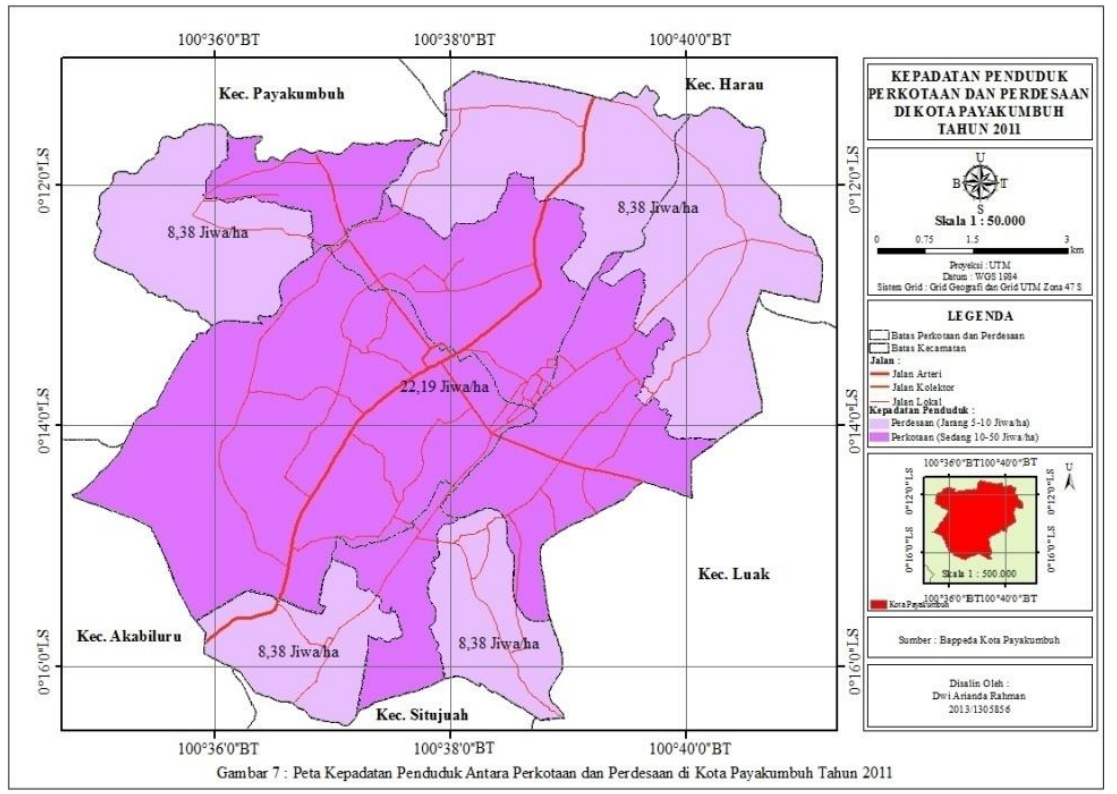

Gambar 3 : Peta Kepadatan Penduduk Perkotaan dan Perdesaan Tahun 2011

c. Kepadatan penduduk antara perkotaan dan perdesaan 2016 
Tabel 3: Hasil Analisis Kepadatan Penduduk Antara Urban (Perkotaan) dan Rural (Perdesaan) di Kota Payakumbuh Tahun 2016

\begin{tabular}{|c|c|r|r|r|r|}
\hline No & Klasifikasi & $\begin{array}{c}\text { Luas } \\
\text { Wilayah } \\
\text { (Ha) }\end{array}$ & $\begin{array}{c}\text { Jumlah } \\
\text { Penduduk } \\
\mathbf{2 0 1 6}\end{array}$ & $\begin{array}{c}\text { Kepadatan } \\
\text { Penduduk } \\
\text { (Jiwa/Ha) }\end{array}$ & Kategori \\
\hline 1 & Perkotaan & 4.308 & 102.627 & 23,82 & Sedang \\
\hline 2 & Perdesaan & 3.218 & 27.180 & 8,44 & Jarang \\
\hline \multicolumn{2}{|c|}{ Jumlah } & 7.526 & 129.807 & 17,24 & Sedang \\
\hline
\end{tabular}

Sumber :Pengelolaan Data Sekunder 2017

Bedasarkan tabel 3, kepadatan penduduk tahun 2016 di perkotaan jauh lebih tinggi dibandingkan dengan kepadatan penduduk di perdesaan. Kepadatan penduduk di perkotaan 23,82 jiwa/ha bertambah 1,63 jiwa/ha dari tahun 2011 dan bertambah 4,71 jiwa/ha dari tahun 2007, sedangkan di perdesaan kepadatan penduduk yaitu 8,44 jiwa/ha bertambah 0,06 jiwa/ha dari tahun 2011 dan bertambah 1,41 jiwa/ha dari tahun 2007. Hal ini menunjukkan kepadatan penduduk di perdesaan tidak mengalami pertambahan yang tinggi dibandingkan dengan perkotaan.

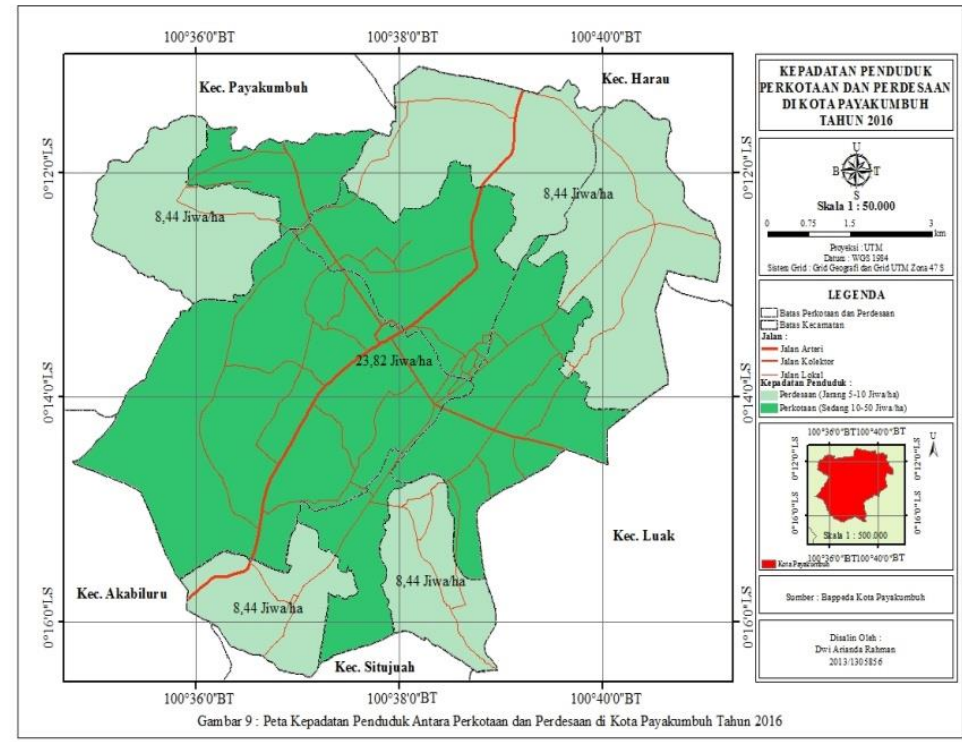

Gambar 4 : Peta Kepadatan Penduduk Antara Perkotaan dan Perdesaan Tahun 2016

Tabel 4 :Hasil Kepadatan Penduduk Antara Perkotaan dan Perdesaan di Kota Payakumbuh 2007,2011, dan 2016

\begin{tabular}{|c|c|r|r|r|}
\hline \multirow{2}{*}{ No. } & \multirow{2}{*}{ Klasifikasi } & \multicolumn{3}{|c|}{ Kepadatan Penduduk Jiwa/ha } \\
\cline { 3 - 5 } & & $\mathbf{2 0 0 7}$ & $\mathbf{2 0 1 1}$ & $\mathbf{2 0 1 6}$ \\
\hline 1 & Perkotaan & 19,11 & 22,19 & 23,82 \\
\hline 2 & Perdesaan & 7,03 & 8,38 & 8,44 \\
\hline
\end{tabular}

Sumber :Pengelolaan Data Sekunder 2017

Bedasarkan tabel 4, kepadatan dibandingkan dengan kepadatan penduduk tahun 2007-2016, kepadatan penduduk di perdesaan. Hal ini penduduk di perkotaan jauh lebih tinggi menunjukkan Kota Payakumbuh 
perkembangan penduduknya masih terfokus pada wilayah perkotaan, yang mana kepadatan penduduknya masih berkembang di wilayah perkotaan.

\section{Pertumbuhan Penduduk Antara Perkotaan dan Perdesaan di Kota Payakumbuh}

Hasil analisis pertumbuhan penduduk diuraikan bedasarkan rumus pertumbuhan penduduk secara geometrik, yang terdapat di Kota Payakumbuh pada tahun 2007-2011, 2011-2016, dan 2007-2016. Pertumbuhan Penduduk merupakan perubahan jumlah penduduk di suatu wilayah tertentu pada waktu tertentu dibandingkan waktu sebelumnya.

a. Pertumbuhan Penduduk Antara Perkotaan dan Perdesaan di Kota Payakumbuh 2007-2011

Bedasarkan hasil analisis pertumbuhan penduduk antara perkotaan dan perdesaan di Kota Payakumbuh tahun 2007-2011 dapat dilihat pada tabel berikut ini :

Tabel 5 :Hasil Analisis Pertumbuhan Penduduk Antara Perkotaan dan Perdesaan di Kota Payakumbuh 2007-2011

\begin{tabular}{|c|c|c|c|c|c|}
\hline \multirow[t]{2}{*}{ No. } & \multirow[t]{2}{*}{ Klasifikasi } & \multicolumn{2}{|c|}{ Jumlah Penduduk } & \multirow{2}{*}{$\begin{array}{l}\text { Pertumbuhan } \\
\text { Penduduk } \\
(\%) \text { pertahun }\end{array}$} & \multirow[t]{2}{*}{ Kategori } \\
\hline & & 2007 & 2011 & & \\
\hline 1 & Perkotaan & 82.343 & 95.617 & 2,15 & Cepat \\
\hline 2 & Perdesaan & 22.630 & 26.975 & 2,54 & Cepat \\
\hline
\end{tabular}

Sumber :Pengelolaan Data Sekunder 2017

Bedasarkan tabel 5, pertumbuhan penduduk tahun 2007-2011 di perdesaan lebih tinggi dibandingkan dengan pertumbuhan penduduk di perkotaan. Hal ini menunjukkan daerah perdesaan sudah mengalami pertumbuhan yang mengimbangi perkembangan daerah perkotaan. Untuk pertumbuhan penduduk di perdesaan 2,54\% pertahun, sedangkan pertumbuhan penduduk di perkotaan $2,15 \%$ pertahun.

b. Pertumbuhan Penduduk Antara Perkotaan dan Perdesaan di Kota Payakumbuh 2007-2011

Tabel 6: Hasil Analisis Pertumbuhan Penduduk Antara Perkotaan dan Perdesaan di Kota Payakumbuh 2011-2016

\begin{tabular}{|c|c|c|c|c|c|}
\hline \multirow[t]{2}{*}{ No. } & \multirow[t]{2}{*}{ Klasifikasi } & \multicolumn{2}{|c|}{ Jumlah Penduduk } & \multirow{2}{*}{$\begin{array}{l}\text { Pertumbuhan } \\
\text { Penduduk } \\
(\%) \text { pertahun }\end{array}$} & \multirow[t]{2}{*}{ Kategori } \\
\hline & & 2011 & 2016 & & \\
\hline 1 & Perkotaan & 95.617 & 102.627 & 1,42 & Lambat \\
\hline 2 & Perdesaan & 26.975 & 27.180 & 0,15 & Sangat lambat \\
\hline
\end{tabular}

Sumber :Pengelolaan Data Sekunder 2017

Bedasarkan tabel 6, pertumbuhan penduduk di perkotaan dan perdesaan tidak mengalami perubahan yang signifikan. Pertumbuhan penduduk di 
perkotaan $1,42 \%$ pertahun sedangkan perdesaan $\quad 0,15 \% \quad$ pertahun. Dibandingkan dengan pertumbuhan penduduk dari tahun 2007-2011, pertumbuhan penduduk 2011-2016 di perkotaaan dan perdesaan mengalami perubahan, pertumbuhan penduduk di perkotaan lebih tinggi dibandingkan dengan pertumbuhan penduduk perdesaan.

c. Pertumbuhan Penduduk Antara Perkotaan dan Perdesaan di Kota Payakumbuh 2007-2016

Tabel 7: Hasil Analisis Pertumbuhan Penduduk Antara Perkotaan dan Perdesaan di Kota Payakumbuh 2007-2016

\begin{tabular}{|c|c|c|c|c|c|}
\hline \multirow[t]{2}{*}{ No. } & \multirow[t]{2}{*}{ Klasifikasi } & \multicolumn{2}{|c|}{ Jumlah Penduduk } & \multirow{2}{*}{$\begin{array}{l}\text { Pertumbuhan } \\
\text { Penduduk } \\
(\%) \text { pertahun }\end{array}$} & \multirow[t]{2}{*}{ Kategori } \\
\hline & & 2007 & 2016 & & \\
\hline 1 & Perkotaan & 82.343 & 102.627 & 2,22 & Cepat \\
\hline 2 & Perdesaan & 22.630 & 27.180 & 1,84 & Lambat \\
\hline
\end{tabular}

Bedasarkan tabel 7 , pertumbuhan penduduk tahun 2007-2016 di perkotaan dan perdesaan tidak berbeda begitu jauh, hal ini menunjukkan pertumbuhan penduduk di perkotaan dan perdesaan seimbang. Pertumbuhan penduduk di perkotaan $2,22 \%$ pertahun, bedasarkan ketentuaan pertumbuhan penduduk bahwa pertumbuhan penduduk di

Tabel 8:Hasil Analisis Pertumbuhan Penduduk Antara Perkotaan dan Perdesaan di Kota Payakumbuh 2007, 2011, dan 2016

\begin{tabular}{|c|l|c|c|c|}
\hline \multirow{2}{*}{ No } & \multirow{2}{*}{ Kategori } & \multicolumn{3}{|c|}{ Pertumbuhan Penduduk (\%) } \\
\cline { 3 - 5 } & & $2007-2011$ & $2011-2016$ & $2007-2016$ \\
\hline 1 & Perkotaan & 2,15 & 1,42 & 2,22 \\
\hline 2 & Perdesaan & 2,54 & 0,15 & 1,84 \\
\hline
\end{tabular}

Sumber :Pengelolaan Data Sekunder 2017

Bedasarkan tabel 8 , pertumbuhan penduduk di perkotaan dan perdesaan tidak berbeda jauh, pertumbuhan penduduk di perkotaan dan perdesaan seimbang, yang mana pertumbuhan penduduk 2007-2011 pertumbuhan di perdesaan lebih tinggi di banding perkotaan, sedangkan untuk perkotaan tergolong cepat, dibandingkan dengan pertumbuhan perdesaan $1,84 \%$ pertahun tergolong lambat.

d. Pertumbuhan Penduduk Antara Perkotaan dan Perdesaan di Kota Payakumbuh 2007, 2011,dan 2016

pertumbuhan penduduk 2011-2016 dan 2007-2016 pertumbuhan penduduk di perkotaan lebih tinggi, namun selisihnya tidak jauh berbeda dengan pertumbuhan penduduk perdesaan.

Berikut peta pertumbuhan penduduk antara perkotaan dan perdesaan di Kota Payakumbuh pada tahun 2007-2016 : 


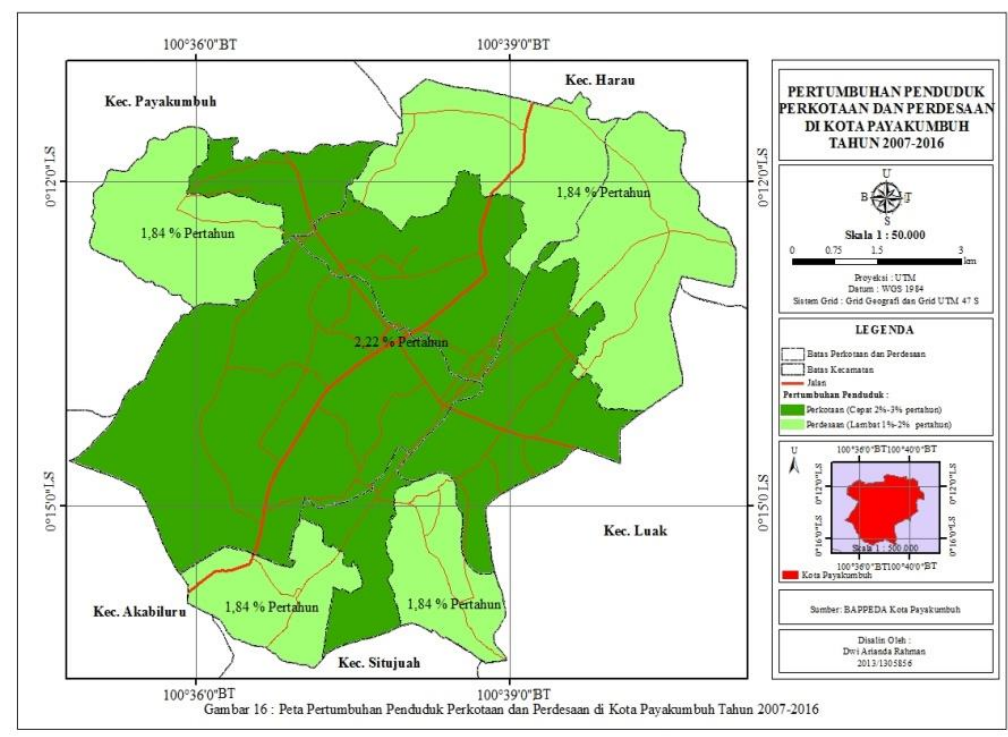

Gambar 5 : Peta Pertumbuhan Penduduk Antara Perkotaan dan Perdesaan Tahun 20072016

\section{Perubahan Penggunaan lahan}

Hasil perubahan penggunaan lahan di Kota Payakumbuh dilakukan dengan interprestasi citra quickbird tahun 2007 dan 2016, interprestasi citra merupakan kegiatan mengkaji citra atau foto udara dengan maksud untuk mengenali objek. Untuk lebih jelasnya perubahan penggunaan lahan di Kota Payakumbuh pada tahun 2007 sampai 2016 dapat dilihat pada tabel berikut ini :

Tabel 9: Hasil Perubahan Penggunaan Lahan Antara Perkotaan dan Perdesaan di Kota Payakumbuh

\begin{tabular}{|c|c|c|c|c|c|c|c|}
\hline \multirow[t]{2}{*}{ No } & \multirow{2}{*}{$\begin{array}{l}\text { Penggunaan } \\
\text { Lahan }\end{array}$} & \multicolumn{2}{|c|}{ Perkotaan } & \multirow{2}{*}{$\begin{array}{l}\text { Perubahan } \\
\text { (ha) }\end{array}$} & \multicolumn{2}{|c|}{ Perdesaan } & \multirow{2}{*}{$\begin{array}{l}\text { Perubahan } \\
\text { (ha) }\end{array}$} \\
\hline & & 2007 & 2016 & & 2007 & 2016 & \\
\hline 1 & Permukiman & 1.182 & 1.631 & +449 & 435 & 660 & +225 \\
\hline 2 & $\begin{array}{l}\text { Ladang/ } \\
\text { Tegalan }\end{array}$ & 1.329 & 967 & -362 & 1.084 & 977 & -107 \\
\hline 3 & Sawah & 1.395 & 1.311 & -84 & 1.596 & 1.478 & -118 \\
\hline 4 & $\begin{array}{c}\text { Lahan } \\
\text { Terbuka }\end{array}$ & 34 & 52 & +18 & 15 & 6 & -9 \\
\hline 5 & $\begin{array}{l}\text { Semak/ } \\
\text { Belukar }\end{array}$ & 368 & 347 & -21 & 88 & 96 & +8 \\
\hline & Jumlah & 4.308 & 4.308 & & 3.218 & 3.218 & \\
\hline
\end{tabular}

Sumber : Pengelolaan Interprestasi Citra Quikbird 2007 dan 2016

Bedasarkan tabel 9, perubahan penggunaan lahan di Kota Payakumbuhdi klasifikasi lima penggunaan lahan yaitu : permukiman, sawah, ladang/tegalan, semak/belukar, dan lahan terbuka. Bedasarkan interprestasi citra bahwa perubahan penggunaan lahan antara perkotaan dan perdesaaan tahun 2007-2016 yang paling tinggi yaitu permukiman, yang mana perubahan permukiman di perkotaan bertambah 449 ha, sedangkan di perdesaan perubahan permukiman bertambah 225 ha. Sedangkan untuk 
perubahan penggunaan lahan yang di perkotaan berkurang 84 ha. paling banyak berkurang yaitu Sedangkan di perdesaan perubahan ladang/tegalan dan sawah, yang mana perubahan ladang/tegalan di perkotaan ladang/tegalan berkurang 107 ha, dan perubahan sawah berkurang 118 ha.

berkurang 362 ha dan perubahan sawah

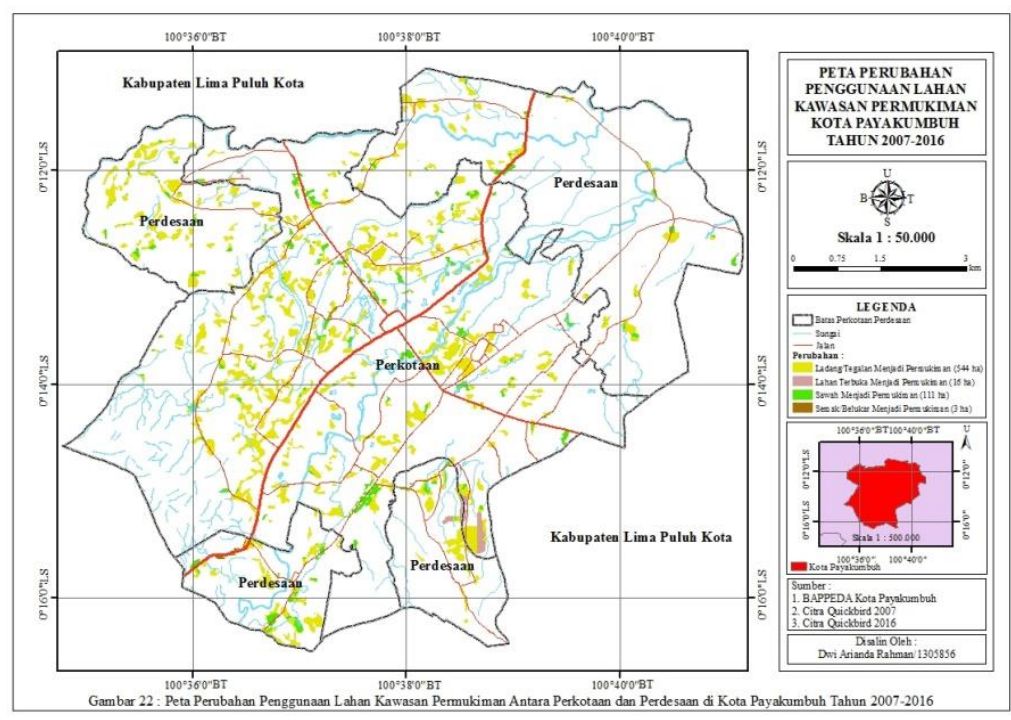

Gambar 6 : Peta Perubahan Penggunaan Lahan Antara Perkotaan dan Perdesaan

Tabel 10 : Hasil Perubahan Penggunaan Lahan Kawasan Permukiman Antara Perkotaan dan Perdesaan di Kota Payakumbuh

\begin{tabular}{|c|c|c|c|c|c|}
\hline \multirow{2}{*}{ No } & Penggunaan Lahan & \multicolumn{4}{|c|}{ Perubahan Permukiman (ha) } \\
\cline { 3 - 6 } & & Perkotaan & $\%$ & Perdesaan & $\%$ \\
\hline 1 & & & & 177 & 79 \\
\hline 2 & Ladang/Tegalan & 366 & 82 & 40 & 18 \\
\hline 3 & Sawah & 72 & 16 & 3 & 1 \\
\hline 4 & Semak/Belukar & - & - & 5 & 2 \\
\hline & Lahan Terbuka & 11 & 2 & 225 & 100 \\
\hline
\end{tabular}

Sumber :Hasil Overlay Penggunaan Lahan Tahun 2007 dan 2016

Bedasarkan tabel 10, bahwa perubahan penggunaan lahan ladang/tegalan mengalami pengurangan yang paling tinggi menjadi kawasan permukiman baik di perkotaan maupun perdesaaan. Perubahan ladang/tegalan menjadi kawasan permukiman di perkotaan yaitu 366 ha, perubahan sawah menjadi kawasan permukiman 72 ha dan perubahan lahan terbuka menjadi kawasan permukiman 11 ha. Sedangkan perubahan ladang/tegalan menjadi kawasan permukiman di perdesaan yaitu 177 ha, perubahan sawah menjadi kawasan permukiman 40 ha, perubahan semak/belukar menjadi kawasan permukiman 3 ha, perubahan lahan terbuka menjadi kawasan permukiman 5 ha.

1. Bedasarkan hasil analisis kepadatan penduduk di Kota Payakumbuh, maka hasil penelitian ini akan membandingkan kepadatan penduduk 
antara perkotaan dan perdesaan, yang mana klasifikasi perkotaan terdapat di 53 kelurahan di Kota Payakumbuh, sedangkan klasifikasi perdesaan terdapat di 23 kelurahan di Kota Payakumbuh. Menurut ketentuan kepadatan penduduk (Munawir, 2005) menyatakan kepadatan penduduk dikelompokkan sangat jarang apabila < 5 jiwa/ha, kepadatan penduduk dikelompokkan jarang apabila5-10 jiwa/ha, kepadatan penduduk dikelompokkan sedang apabila 10-50 jiwa/ha, kepadatan penduduk dikelompokkan padat apabila 50-100 jiwa/ha, kepadatan penduduk dikelompokkan sangat padat apabila > 100 jiwa/ha. Perbandingan kepadatan penduduk antara perkotaan dan perdesaan di Kota Payakumbuh pada tahun 2007-2016, kepadatan penduduk di perkotaan yaitu 19,11-23,82 jiwa/ha, yang artinya dalam 1 ha terdapat 19-23 jiwa. Sedangkan kepadatan penduduk di perdesaan yaitu 7,03-8,38 jiwa/ha, yang artinya dalam 1 ha terdapat 7-8 jiwa. Makadapat disimpulkan kepadatan penduduk di perkotaan berada pada kategori kepadatan penduduk sedang. Sedangkan kepadatan penduduk di perdesaan berada pada kategori kepadatan penduduk jarang.

Hal ini sesuai dengan pernyataan (Munawir,2005) Kepadatan penduduk daerah satu dengan daerah tidak seimbang karena persebaran penduduk yang tidak merata. Kepadatan penduduk erat kaitannya dengan kemampuan wilayah yang mendukung kehidupan penduduknya dan daya dukung lingkungan di masing-masing daerah tidaklah sama antara suatu daerah dengan daerah lain.

Bedasarkan hasil penelitian yang ditemukan bahwa kepadatan penduduk di perkotaan tergolong sedang sedangkan di perdesaan kepadatan penduduknya tergolong jarang. Hal ini menunjukkan bahwa Kota Payakumbuh masih tergolong kota sedang ataupun berkembang, dilihat dari kepadatan penduduknya belum tergolong padat di kawasan perkotaan, karena masih banyak lahan kosong untuk dijadikan tempat tinggal, sedangkan di perdesaan masih banyaknya lahan untuk pertanian.

2. Bedasarkan hasil analisis pertumbuhan penduduk di Kota Payakumbuh, maka hasil penelitian ini akan membandingkan pertumbuhan penduduk antara perkotaan dan perdesaan. Menurut (Wirosuhardjo, 2004) menyatakan pertumbuhan penduduk digolongkan menjadi sangat lambat, lambat, cepat dan sangat cepat. Pertumbuhan penduduk dikatakan sangat lambat jika laju pertumbuhan penduduk kurang dari $1 \%$ pertahun, pertumbuhan penduduk dikatakan lambat jika laju pertumbuhan penduduk antara $1-2 \%$ per tahun, pertumbuhan penduduk dikatakan cepat jika laju pertumbuhan penduduk di atas 2-3\% pertahun dan pertumbuhan penduduk dikatakan sangat cepat jika laju pertumbuhan penduduk besar dari 3\% pertahun. Perbandingan pertumbuhan penduduk antara perkotaan dan perdesaan di Kota Payakumbuh pada tahun 2007-2016, pertumbuhan penduduk di perkotaan yaitu $2,22 \%$ pertahun, sedangkan pertumbuhan penduduk di perdesaan yaitu 1,84. 
Maka dapat disimpulkan pertumbuhan penduduk di perkotaan berada pada kategori pertumbuhan penduduk cepat. Sedangkan pertumbuhan penduduk di perdesaan berada pada kategori pertumbuhan penduduk lambat.

Hal ini sesuai dengan pernyataan Munir (1985) setiap perubahan jumlah penduduk, baik pertambahan ataupun pengurangan disebut pertumbuhan, dapat positif atau negatif. Pada hakikatnya suatu pertumbuhan penduduk hanya berpangkal pada tiga sumber, yaitu kelahiran, kematian, dan migrasi. Pertumbuhan penduduk sama sekali bukan merupakan aspek yang terpisah dari pada eksistensi penduduk, tetapi justru merupakan akibat berbagai faktor khusus.

Bedasarkan hasil penelitian yang ditemukan bahwa pertumbuhan di perkotaan tergolong cepat sedangkan di perdesaan kepadatan penduduknya tergolong lambat. Hal ini menunjukkan pertumbuhan dan perkembangan penduduk di Kota Payakumbuh masih terfokus pada daerah perkotaan, karena disebabkan tingginya konsentrasi di perkotaan dalam sektor perdagangan, jasa, perkantoran dan arus lalu lintas yang tinggi, hal ini akan mengakibatkan pertumbuhan dan perkembangan di perdesaan menjadi lambat.

3. Perubahan penggunaan lahan di Kota Payakumbuh terdiri dari lima klasifikasi yaitu permukiman, sawah, ladang/tegalan, lahan terbuka, dan semak/belukar. Klasifikasi penggunaan lahan yang bertambah paling tinggi yaitu kawasan permukiman. Perubahan penggunaan lahan ini yaitu dari ladang/tegalan, sawah, dan lahan terbuka berubah menjadi lahan permukiman. Sehingga permukiman di Kota Payakumbuh mengalami perubahan dari tahun 2007 sampai 2016 bertambah 674 ha. Untuk perubahan penggunaan lahan kawasan permukiman antara perkotaan dan perdesaan, bahwa perubahan permukiman di perkotaan lebih tinggi di bandingkan dengan perdesaan, di perkotaan perubahan penggunaan lahan untuk kawasan permukiman dari tahun 2007-2016 bertambah 449 ha, sedangkan di perdesaan perubahan penggunaan lahan kawasan permukiman bertambah 225 ha, hal ini menunjukkan bahwa perubahan kawasan permukiman antara perkotaan dan perdesaan selalu bertambah. Bedasarkan hasil interprestasi citra, perubahan penggunaan lahan ladang/tegalan mengalami pengurangan yang paling tinggi menjadi kawasan permukiman baik di perkotaan maupun perdesaaan. Perubahan ladang/tegalan menjadi kawasan permukiman di perkotaan yaitu 366 ha, perubahan sawah menjadi kawasan permukiman 72 ha dan perubahan lahan terbuka menjadi kawasan permukiman 11 ha. Sedangkan perubahan ladang/tegalan menjadi kawasan permukiman di perdesaan yaitu 177 ha, perubahan sawah menjadi kawasan permukiman 40 ha, perubahan semak/belukar menjadi kawasan permukiman 3 ha, perubahan lahan terbuka menjadi kawasan permukiman 5 ha.

Hal ini sesuai dengan pernyataan (Wahyudi, 2005) menjelaskan bahwa perubahan penggunaan lahan adalah perubahan penggunaan lahan dari fungsi 
tertentu misalnya dari sawah berubah menjadi permukiman atau tempat usaha, dari sawah berubah menjadi irigasi atau yang lainnya. Faktor-faktor yang mendorong perubahan penggunaan lahan adalah politik, ekonomi, demografi dan budaya. Demografi adalah salah satu faktor yang mendukung perubahan penggunaan lahan terutama perubahan penggunaan lahan permukiman. Perubahan lahan juga bisa disebabkan adanya kebijaksanaan pemerintah dalam melaksanakan pembangunan di suatu wilayah.

Hal ini menunjukkan, dengan adanya kepadatan dan pertumbuhan penduduk yang semakin bertambah dari tahun ke tahun, hal ini akan mengakibatkan kebutuhan lahan untuk kawasan permukiman juga akan bertambah. Hal ini sesuai dengan kepadatan dan pertumbuhan penduduk, yang mana kepadatan dan pertumbuhan penduduk di perkotaan lebih tinggi dibandingkan kepadatan dan pertumbuhan penduduk di perdesaan. Jadi, dapat disimpulkan jika kepadatan dan pertumbuhan penduduk tinggi, maka penggunaan lahan untuk kawasan permukiman juga akan tinggi dan bertambah.

\section{PENUTUP}

\section{Kesimpulan}

Kepadatan penduduk antara perkotaan dan perdesaan di Kota Payakumbuh pada tahun 2007-2016, bahwa kepadatan penduduk di perkotaan tergolong sedang. Sedangkan kepadatan penduduk di perdesaan tergolong jarang. Hal ini menunjukkan bahwa Kota Payakumbuh masih tergolong kota sedang ataupun berkembang karena kepadatan penduduknya belum tergolong padat di kawasan perkotaan.

Pertumbuhan penduduk antara perkotaan dan perdesaan di Kota Payakumbuh pada tahun 2007-2016, bahwa pertumbuhan penduduk di perkotaan tergolong cepat. Sedangkan pertumbuhan penduduk di perdesaan tergolong lambat. Hal ini menunjukkan pertumbuhan dan perkembangan penduduk di Kota Payakumbuh masih terfokus pada daerah perkotaan.

Perubahan penggunaan lahan di Kota Payakumbuh terdiri dari lima klasifikasi yaitu permukiman, sawah, ladang/tegalan, lahan terbuka, dan semak/belukar. Klasifikasi penggunaan lahan yang bertambah paling tinggi yaitu kawasan permukiman. Perubahan penggunaan lahan ini yaitu dari ladang/tegalan, sawah, dan lahan terbuka berubah menjadi lahan permukiman. Sehingga permukiman di Kota Payakumbuh mengalami perubahan dari tahun 2007 sampai 2016 bertambah 674 ha. Untuk perubahan penggunaan lahan kawasan permukiman di perkotaan dari tahun 2007-2016 bertambah 449 ha, sedangkan di perdesaan perubahan penggunaan lahan kawasan permukiman bertambah 225 ha. Bedasarkan hasil interprestasi citra, perubahan penggunaan lahan ladang/tegalan mengalami pengurangan yang paling tinggi menjadi kawasan permukiman baik di perkotaan maupun di perdesaan. Perubahan ladang/tegalan menjadi kawasan permukiman di 
perkotaan yaitu 366 ha. Sedangkan perubahan ladang/tegalan menjadi kawasan permukiman di perdesaan yaitu 177 ha.

\section{Saran}

Diharapkan kepadatan penduduk di Kota Payakumbuh baik perkotaan dan perdesaan seimbang, tidak terfokus pada perkotaan sehingga terjadinya pemerataan penduduk di perkotaan dan perdesaan. Jika penduduknya sudah merata maka mendorong terjadinya pemerataan pertumbuhan dan pembangunan di perdesaan.

Diharapkan kepada pemerintah dan masyarakat agar dalam pengelolaan penggunaan lahan untuk kawasan permukiman tidak merugikan penggunaan lahan lainnya, sehingga kualitas lingkungan tetap terjaga dan seimbang.

\section{DAFTAR PUSTAKA}

Arikunto, Suharsimi. 2010. Prosedur Penelitian. Jakarta. : Rineka Cipta.

Badan Pusat Statistik Kota Payakumbuh. 2007. Kecamatan Dalam Angka 2008.

Badan Pusat Statistik Kota Payakumbuh. 2010. Kecamatan Dalam Angka 2011.

Badan Pusat Statistik Kota Payakumbuh. 2011. Kecamatan Dalam Angka 2012.

Badan Pusat Statistik Kota Payakumbuh. 2016. Kecamatan Dalam Angka 2017.

Badan Pusat Statistik Nomor 37 Tahun 2010 Tentang Klasifikasi Perkotaan dan Perdesaan.
Munawir, dkk. 2005. Cakrawala Geografi. Jakarta : Yudistira.

Munir, dan Budiharto. 1990. TeoriTeori Kependudukan. Jakarta : Rineka Cipta.

Munir, Rozy. Ed. 1985. Pendidikan Kependudukan. Jakarta : PT. Bumi Aksara.

Undang-Undang Penataan Ruang No. 26 Tahun 2007 Tentang Kawasan Perkotaan

Wahyudi. 2005. Analisis Perubahan Penggunaan Lahan di Kecamatan Sokaraja Kabupaten Banyumas Tahun 1994-2004 (Skripsi). Universitas Muhammadiyah Surakarta.

Wirosuhardjo, K. 2004. Dasar-Dasar Demografi. Jakarta : FEUI 